\title{
PERBANDINGAN HASIL BELAJAR SISTEM KOLOID DENGAN MENERAPKAN MODEL PEMBELAJARAN KOOPERATIF TIPE NUMBERED HEAD TOGETHER (NHT) DAN TEAM GAMES TOURNAMENT (TGT) DI SMA
}

\author{
Oktariani \\ Universitas Islam Riau \\ E-mail: rhini03okt@yahoo.com
}

\begin{abstract}
Abstrak: Pembelajaran kimia di SMA X masih belum maksimal sehingga berdampak terhadap hasil belajar yang belum memenuhi KKM yaitu $\geq 75$. Pembelajaran kimia khususnya sistem koloid di SMA X masih terpusat pada kemampuan siswa untuk menghapal tanpa menghubungkannya dengan kehidupan sehari-hari. Untuk mengatasi hal ini diterapakan model pembelajaran kooperatif tipe NHT dan TGT. Tujuan penelitian ini adalah untuk memperoleh perbedaan hasil belajar sistem koloid dengan menerapkan model pembelajaran NHT dan TGT. Jenis penelitian ini adalah penelitian eksperiman dengan rancangan Randomized Control Group Only Design yang diperluas. Populasi dalam penelitian ini adalah siswa kelas XI IA di X, dan sampel penelitian ini adalah siswa kelas XI IA 2 sebagai kelas eksperimen 1 (NHT) dan siswa kelas XI IA 3 sebagai kelas eksperimen 2 (TGT). Sampel diperoleh dengan menggunakan teknik Purposive Sampling. Data diperoleh dari tes hasil belajar kognitif yang diberikan di akhir pembelajaran, dimana soal tes akhir ini telah diujicobakan terlebih dahulu. Data tersebut kemudian dianalisis secara statistik dengan menggunakan uji-t. Hasil analisis data hasil belajar kognitif diperoleh rata-rata kelas eksperimen $1(\mathrm{NHT})=81,8$ dan kelas eksperimen $2($ TGT $)=80,8$. Dari hasil uji-t yang dilakukan pada taraf nyata 0,05 diperoleh $t_{\text {hitung }}=0,42$ dan $\mathrm{t}_{\text {tabel }}=2,00(\mathrm{dk}=73)$, terlihat bahwa $\mathrm{t}_{\text {hitung }}<\mathrm{t}_{\text {tabel }}$ maka $\mathrm{H}_{0}$ diterima sedangkan $\mathrm{H}_{1}$ ditolak, yang artinya kedua kelas sampel tidak memiliki perbedaan yang signifikan. Akan tetapi dapat meningkatakan hasil belajar, hal ini terlihat dari nilai rata-rata kelas sampel yang memenuhi KKM yaitu $\geq 75$.
\end{abstract}

Kata kunci: Pembelajaran kooperatif, TGT, NHT, sistem koloid.

\section{PENDAHULUAN}

Kimia adalah salah satu mata pelajaran yang membahas mengenai materi dan perubahan yang terjadi di dalamnya. Tanpa kita sadari kimia memberikan banyak masukan bagi perkembangan ilmu pengetahuan dan teknologi. Dalam kehidupan seharihari kita tidak bisa lepas dari kimia, mulai dari udara yang kita hirup hingga makanan dan minuman kita konsumsi sehari-hari semuanya merupakan senyawa atau bahan kimia. Saat ini, mata pelajaran kimia merupakan salah satu mata pelajaran IPA yang termasuk pada Ujian Nasional untuk tingkat SMA dan MA. Untuk itu berbagai upaya dilakukan agar pembelajaran kimia bisa dipahami sejak dini, salah satunya dengan menggunakan berbagai metode pembelajaran yang menarik dan sesuai dengan karakteristik dari pelajaran tersebut.

Berdasarkan pengalaman selama melaksanakan program praktek lapangan di SMAN X, dapat disimpulkan bahwa proses pembelajaran masih belum maksimal. Hal ini terlihat dari berbagai fakta yang ditemukan dilapangan berupa kurangnya aktivitas siswa dalam proses pembelajaran kimia, interaksi antar siswa dan siswa dengan guru masih kurang. Interaksi terjadi antara guru dengan beberapa siswa saja sedangkan sebagian lagi sibuk dengan aktivitas masing-masing yang tidak ada hubungannya dengan pembelajaran. Selain itu, siswa belum mampu merekontruksi konsep dan proses pembelajaran masih bergantung pada pangarahan kemampuan siswa untuk menghafal informasi kemudian dilanjutkan dengan mengerjakan latihan tanpa diikuti oleh kemampuan untuk memahami informasi yang dihafal tersebut dan menghubungkannya dengan kehidupan sehari-hari. Proses tersebut menyebabkan siswa sulit untuk menyelesaikan soal-soal yang diberikan, 
sehingga berdampak terhadap hasil belajar yang dicapai. Hal ini terlihat dari data nilai rata-rata ulangan harian pokok bahasan sistem koloid siswa kelas XI IA di SMA X yang masih belum memenuhi Kriteria Ketuntasan Minimum (KKM) yaitu 75.

Salah satu materi pembelajaran kimia SMA yang paling banyak berhubungan dengan kehidupan sehari-hari dan sebagian besar bersifat teoritis adalah sistem koloid. Untuk itu, agar materi pembelajaran ini lebih bermakna diperlukan model pembelajaran yang dapat meningkatkan aktivitas siswa dan interaksi antar siswa atau siswa dengan guru sehingga siswa terlibat secara efektif dan proses pembelajaran menjadi lebih maksimal dan bermakna. Salah satunya dengan menggunakan model pembelajaran kooperatif. Menurut Suyatno (2009), model pembelajaran kooperatif sangat baik dikembangkan dalam proses pembelajaran terutama pokok bahasan yang didominasi oleh materi yang bersifat teoritis. Pembelajaran kooperatif merupakan suatu model pembelajaran, dimana siswa belajar dalam kelompok kecil dengan tingkat kemampuan yang berbeda. Model pembelajaran NHT dirancang untuk meningkatkan interaksi antar siswa dan siswa dengan guru.

Selain NHT, Model pembelajaran TGT juga dapat digunakan dalam materi pembelajaran Sistem Koloid ini. Penelitian tentang model pembelajaran kooperatif tipe TGT ini sebelumnya juga sudah banyak dilakukan. Berdasarkan uraian tersebut diatas, maka penulis tertarik untuk melakukan suatu penelitian yang berjudul: "Perbandingan Hasil Belajar Sistem Koloid dengan Menerapkan Model Pembelajaran kooperatif tipe Number Heads Together (NHT) dan Teams Games Tournament (TGT) di SMA”.

\section{METODE PENELITIAN}

Sesuai dengan permasalahan penelitian, maka jenis penelitian ini adalah penelitian eksperimen. Adapaun rancangan dalam penelitian ini adalah "Randomized Control Group Only Design yang Diperluas” yang digambarkan sebagai berikut :

Tabel 1. Rancangan penelitian

\begin{tabular}{llll}
\hline Kelas & Pretest & Treatment & Postest \\
\hline $\begin{array}{l}\text { Eksperimen } \\
\text { 1(XI IA 2) }\end{array}$ & - & $\mathrm{X}_{1}$ & $\mathrm{~T}$ \\
$\begin{array}{l}\text { Eksperimen } \\
\text { 2(XI IA 3) }\end{array}$ & & $\mathrm{X}_{2}$ & $\mathrm{~T}$
\end{tabular}

Sumber: (Suryabrata, 2005: 106)

Keterangan:
$\mathrm{X}_{1}=$ Perlakuan yang diberikan pada kelas eksperimen 1 yaitu pembelajaran kooperatif tipe NHT
$\mathrm{X}_{2}=$ Perlakuan yang diberikan padakelas eksperimen 2 yaitu pembelajaran kooperatif tipe TGT
$\mathrm{T}=\quad$ Tes akhir yang diberikan pada kedua kelas sampel di akhir penelitian.

Populasi dalam penelitian ini adalah siswa kelas XI IA SMA X, yang terdiri dari tiga kelas. Sampel penelitian yaitu dua kelas eksperimen, sebagai kelas eksperimen 1 dan kelas eksperimen 2. Pengambilan sampel dilakukan menggunakan teknik purposive sampling. Purposive sampling adalah teknik sampling yang digunakan peneliti jika 
peneliti mempunyai pertimbangan untuk tujuan tertentu. Teknik ini biasanya dilakukan karena beberapa pertimbangan, misalnya alasan keterbatasan waktu, tenaga, dana, sehingga tidak dapat mengambil sampel yang besar dan jauh. Adapun variabel-variabel dalam penelitian ini adalah: (1) Variabel Bebas yaitu model pembelajaran NHT untuk kelas eksperimen 1 dan model pembelajaran TGT untuk kelas eksperimen 2; (2) Variabel Terikat yaitu hasil belajar kimia siswa dari kedua kelas eksperimen; (3) Variabel Kontrol yaitu materi, guru yang mengajar, penggunaan sarana dan prasarana.

Dalam penelitian ini, terdapat berbagai jenis data yaitu: Data primer berupa data yang langsung diambil melalui tes hasil belajar kimia siswa diakhir pembelajaran dan data sekunder, yaitu jumlah siswa kelas XI yang mengikuti program IPA yang terdaftar pada semester 2 dan nilai ulangan mid semester siswa kelas XI IA pada mata pelajaran kimia. Alat pengumpul data untuk penilaian hasil berupa tes akhir dengan tipe yang digunakan adalah tes objektif dengan 5 option yang diberikan pada kelas sampel yang diteliti. Tes yang diujikan sesuai dengan materi yang diberikan selama perlakuan berlangsung yang dilaksanakan diakhir pembelajaran. untuk mendapatkan tes akhir yang baik terlebih dahulu dibuat kisi-kisi soal untuk dilakukan uji coba tes. Tes uji coba ini, dilakukan di sekolah yang sama dengan sekolah tempat penelitian tetapi kelas yang berbeda dengan kelas yang akan diadakan penelitian. Setelah dilakukan uji coba soal didapatkan distribusi skor tes. Selanjutnya soal-soal tersebut dianalisis untuk mendapatkan soal tes yang baik. Adapun hal-hal yang perlu dianalisis meliputi: validitas tes, reliabilitas tes, indeks kesukaran, dan daya beda.

Sudjana (2002) menyatakan bahwa untuk menganalisis data hasil penelitian ini dilakukan uji hipotesis yaitu uji perbedaan dua rata-rata atau uji-t. Sebelum melakukan uji-t terlebih dahulu dilakukan uji normalitas dan uji homogenitas.

\section{HASIL DAN PEMBAHASAN}

Hasil analisis data hasil belajar kognitif diperoleh rata-rata kelas eksperimen $1=81,8$ dan kelas eksperimen $2=80,8$. Dari hasil uji-t yang dilakukan pada taraf nyata 0,05 diperoleh $\mathrm{t}_{\text {hitung }}=$ 0,42 dan $\mathrm{t}_{\text {tabel }}=2,00(\mathrm{dk}=73)$, terlihat bahwa $\mathrm{t}_{\text {hitung }}<\mathrm{t}_{\text {tabel }}$ maka $\mathrm{H}_{0}$ diterima sedangkan $\mathrm{H}_{1}$ ditolak, yang artinya kedua kelas sampel tidak memiliki perbedaan yang signifikan. Akan tetapi dapat meningkatakan hasil belajar, hal ini terlihat dari nilai rata-rata kelas sampel yang memenuhi KKM yaitu $\geq 75$.

Seperti yang sudah dijelaskan pada sub bab karakteristik materi, pada pokok bahasan sistem koloid ini terdapat 6 indikator pembelajaran dimana sebagian besar bersifat teoritis dan berhubungan dengan kehidupan sehari-hari. Untuk indikator pembelajaran 1 dan 2 yakni mengelompokkan campuran yang ada di lingkungannya ke dalam suspensi kasar, dan sistem koloid dan menyimpulkan perbedaannya serta mengelompokkan jenis koloid berdasarkan fase terdispersi dan fase pendispersinya hasil belajar per indikator menunjukkan bahwa kelas eksperimen 1 (NHT) memiliki hasil belajar yang lebih rendah dibandingkan kelas eksperimen 2 (TGT). Dalam pelaksanaan pembelajaran kedua kelas eksperimen, siswa menemukan konsep-konsep dasar mengenai pengertian dan jenis-jenis koloid melalui demonstrasi dan menggunakan media berupa power point, sedangkan pada tahap elaborasi dan konfirmasi kedua kelas ekperimen ini memiliki tahapan yang berbeda.

Untuk indikator pembelajaran 3 dan 5 yakni menjelaskan sifat-sifat koloid dan proses pembuatan berdasarkan percobaan, kedua kelas eksperimen tidak menunjukkan perbedaan hasil belajar karena semua siswa memenuhi ketuntasan. Pada indikator ini siswa menemukan konsepnya melalui pengamatan dan media power point kemudian diikuti oleh diskusi kelompok dan kuis individual untuk kelas eksperimen 1 dan tournament untuk kelas eksperimen 2,sehingga siswa lebih banyak berinteraksi baik antar 
siswa maupun siswa dengan guru dan banyak melakukan aktivitas belajar. Hal ini memiliki dampak positif terhadap hasil belajar, sesuai dengan pendapat Nasution (1995: 89) yang menyatakan bahwa makin banyak siswa melakukan aktivitas dalam belajar, maka makin dalam pelajaran itu dapat dikuasainya".

Sementara itu, untuk indikator 4 dan 6 yakni menjelaskan koloid liofil dan liofob serta pebedaan keduanya dan menjelaskan aplikasi dari koloid dalam kehidupan seharihari pada industri kosmetik, makanan, dan farmasi, kedua kelas eksperimen menunjukkan hasil belajar yang berbeda, dimana hasil belajar kelas eksperimen 1 (NHT) lebih tinggi dibandingkan hasil belajar kelas eksperimen 2 (TGT). Untuk kedua indikator ini siswa menemukan konsepnya melalui penjelasan guru dengan menggunakan media power point kemudian siswa mengembangkannya dengan mencari informasi dari buku paket atau bahan ajar. Untuk kelas eksperimen 1 (NHT) dalam diskusi kelompok semua anggota kelompok harus dipastikan menguasai konsep dan pertanyaan yang telah diberikan sebagai persiapan untuk diskusi dan kuis individual sedangkan untuk kelas eksperimen 2 (TGT) setelah siswa berdiskusi di kelompoknya kemudian diadakan tournament kelompok, sehingga aktivitas siswa pada kelas eksperimen 1 lebih tinggi dibandingkan kelas ekperimen 2. Aktivitas siswa selama proses pembelajaran dapat mendorong proses berpikir sehingga dapat meningkatkan pemahaman siswa. Hal ini sesuai dengan pendapat Gunawan (2007:350) bahwa "Proses aktivasi merupakan proses yang membawa siswa kepada satu tingkat pemahaman yang lebih dalam terhadap materi yang diajarkan".

Selain itu, untuk hasil belajar siswa secara keseluruhan dari hasil analisis data yang dilakukan juga diperoleh bahwa hasil belajar siswa pada ranah kognitif berupa nilai rata-rata kelas eksperimen 1 yaitu 81,8 dengan simpangan baku 11,2 lebih tinggi dari pada nilai rata-rata kelas eksperimen 2 yaitu 80,8 dengan simpangan baku 9,4. Hanya saja setelah dilakukan pengolahan data secara statistik diketahui bahwa perbedaan hasil belajar dari kedua kelas sampel pada ranah kognitif tidak terlalu signifikan. Dengan menggunakan uji $\mathrm{t}$, diperoleh $\mathrm{t}_{\text {hitung }}=0,42$ dan $\mathrm{t}_{\text {tabel }}=2$ pada taraf nyata 0,05 . Dari perhitungan uji hipotesis terlihat bahwa $t_{\text {hitung }}$ berada pada daerah penerimaan Ho yaitu -2 $<\mathrm{t}<2$. Dengan arti kata hipotesis nol (Ho) diterima dan hipotesis kerja yang berbunyi: "terdapat perbedaan yang signifikan dari hasil belajar kimia dengan menggunakan model pembelajaran kooperatif tipe Numbered Head Together (NHT) dan Teams Games Tournament (TGT) pada pokok bahasan Sistem Koloid di SMA X" ditolak pada taraf signifikan $0,05 \mathrm{dan} \mathrm{dk}=73$. Dengan ditolaknya hipotesis kerja, ini berarti tidak terdapat perbedaan hasil belajar siswa pada pokok bahasan sistem koloid dengan menerapkan model pembelajaran kooperatif tipe NHT dan TGT.

Dalam model pembelajaran kooperatif tipe NHT dan TGT siswa diberikan kesempatan untuk saling berinteraksi, berdiskusi dengan kelompoknya sehingga timbul kerjasama antarsiswa dalam mengkontruksi konsep dan menyelesaikan masalah. Dalam berdiskusi setiap siswa memiliki kesempatan dan peluang yang sama untuk mengemukakan pendapat dan memberikan penjelasan kepada temannya, sehingga dalam diskusi siswa yang berkemampuan tinggi memberikan penjelasan kepada siswa yang berkemampuan rendah atau dengan kata lain siswa saling memberikan penjelasan kepada masing-masing anggota kelompoknya yang belum mengerti tentang materi yang dipelajari. Siswa juga harus memastikan bahwa setiap anggota kelompoknya harus mengetahui dan menguasai pertanyaan dan bahan diskusi yang diberikan untuk persiapan diskusi kelas, kuis individual, maupun turnamen kelompok. Hal ini sejalan dengan pendapat Ibrahim, dkk (2010:7-10) yang menyatakan bahwa model pembelajaran kooperatif dikembangkan untuk mencapai tujuan berupa pencapaian hasil belajar yang baik, penerimaan terhadap perbedaan individu serta mengembangkan keterampilan sosial siswa untuk bekerjasama dan berkolaborasi. 
Pada dasarnya perbedaan pelaksanaan pembelajaran kooperatif dari kedua tipe ini hanya terletak pada kuis individual dan turnamen kelompok saja. Pada kelas eksperimen 1 (NHT) dilaksanakan kuis individual setiap akhir pertemuan. Sedangkan pada kelas eksperimen 2 (TGT), disetiap akhir pertemuan diadakan turnamen kelompok, dimana soal turnamen dibuat oleh masing-masing kelompok. Walaupun demikian jika dilihat dari rata-rata kelas yang diperoleh, baik pada kelas eksperimen 1 maupun kelas eksperimen 2 keduanya sama-sama telah mencapai kriteria ketuntasan minimum yang telah ditetapkan di SMA X yakni $\geq 75$.

Peningkatan hasil belajar ini disebabkan oleh adanya diskusi kelompok dan diskusi kelas sehingga terjadi interaksi antarsiswa dan siswa dengan guru, serta adanya kuis individual maupun turnamen kelompok diakhir pertemuan yang meyebabkan siswa termotivasi untuk belajar dan aktif berdiskusi dalam kelompoknya agar mendapatkan hasil yang terbaik bagi kelompoknya dan mendapatkan penghargaan dari guru dan teman sekelas. Hal ini sesuai dengan pendapat Syah (2005:152) bahwa "Pujian dan hadiah, peraturan/tata tertib sekolah, suri teladan orangtua, dan seterusnya merupakan contohcontoh konkret motivasi ekstrinsik yang dapat menolong siswa dalam belajar".

Dalam melaksanakan penelitian penulis menemukan kendala berupa keterbatasan waktu. Untuk mengatasi hal ini siswa mengerjakan LKS secara berkelompok dan setelah LKS dikerjakan dan dikoreksi bersama-sama. Kemudian LKS tersebut diperbanyak untuk masing-masing kelompok sebagai bahan belajar siswa di rumah dan untuk bahan ajar ataupun panduan materi diberikan beberapa hari sebelum kegiatan pembelajaran dilaksanakan, sehingga siswa bisa membaca dan mempelajari terlebih dahulu. Selain itu, ada beberapa kelompok yang tidak ikut berpartisipasi karena tidak ada kecocokan dengan teman sekelompoknya. Hal ini sesuai dengan pendapat Sagala (2009:216) bahwa "kelemahan dalam metode kerja kelompok adalah a) sulit untuk membuat kelompok yang homogen, baik inteligensi, bakat dan minat, atau daerah tempat tinggal; b) siswa yang oleh guru telah dianggap homogen, sering tidak merasa cocok dengan anggota kelompoknya". Namun, hal ini dapat diatasi dengan melakukan penataan ulang anggota kelompok untuk pertemuan selanjutnya.

\section{KESIMPULAN}

Berdasarkan analisis data dan pembahasan, maka dapat diambil kesimpulan bahwa tidak terdapat perbedaan yang signifikan dari hasil belajar sistem koloid pada aspek kognitif dengan menerapkan model pembelajaran kooperatif tipe Numbered Head Together (NHT) dan Teams Games Tournament (TGT) di SMA X.

\section{DAFTAR RUJUKAN}

Gunawan, Adi. (2007). Genius Learning Strategy. Jakarta: PT Gramedia Pustaka Utama Ibrahim, Muslimin, dkk. (2008). Pembelajaran Kooperatif. Surabaya: Universitas Negeri Surabaya.

Nasution, S. (1995). Didaktik Asas Asas Mengajar. Jakarta: Bumi Aksara

Sagala, Syaiful. 2009. Konsep dan Makna Pembelajaran Untuk Membantu Memecahkan Problematika Belajar dan Mengajar. Bandung: Alfabeta.

Sudjana. 2002. Metode Statistika. Bandung : Transito.

Suryabrata, Sumadi. 2005. Metodologi Penelitian. Jakarta : PT. Raja Grafindo Persada.

Suyatno. 2009. Menjelajah Pembelajaran Inovatif. Sidoarjo: PT.Masmedia Buana Pustaka. 
Syah, Muhibbin. 2005. Psikologi Pendidikan. Jakarta: PT Raja Grafindo Persada 